\title{
Impact of Soil Heat Flux on Water Use of Quinoa
}

\author{
Gehan, G. Abdel-Ghany and Magdy, H. Zaky \\ Desert Research Center, Mataria, Cairo, Egypt \\ Corresponding author: gehang364@gmail.com
}

\begin{abstract}
s
A field study was conducted in the winter season of 2017 at the Agricultural Experimental Station of Wadi Suder, south Sinai (D.R.C.), to evaluate the effect of soil organic matter and applied irrigation water on soil thermal conductivity, soil heat flux consequently on soil evaporation, actual water evapotranspiration (ETa) and water use efficiency (WUE) of quinoa yield(chenopodium quinoa willd). Theoretical water evapotranspiration (ETo) was calculated for each treatment using Penman-Monteith equations. Water use efficiency (WUE) was calculated as a result of cumulative improvement for studied parameters. The results reveal that soil thermal conductivity increases by 24,26 and $65 \%$ as increasing of applied water, organic matter and their interaction, respectively. While, soil heat flux correlated significantly with all treatments and soil heat conductivity. Generally, the increases were 71,86 and $232 \%$ for organic matter, applied water and inter action, respectively. Whereas, soil heat flux increase by $0.02 \mathrm{mj} / \mathrm{m}^{2} /$ day as a result of increasing thermal conductivity by 9.33 $\mathrm{cal} / \mathrm{cm} / \mathrm{s} /{ }^{\circ} \mathrm{c}$ (each $1 \mathrm{cal} / \mathrm{cm} / \mathrm{s} /{ }^{\circ} \mathrm{c}$ of thermal conductivity enhanced heat flux by $0.002 \mathrm{mj} / \mathrm{m}^{2} /$ day). Evaporation from soil surface increase by $0.008 \mathrm{~mm} /$ day as heat flux increase by $0.021 \mathrm{mjm}^{-2}$ day, whilst, increasing soil heat flux $\left(1 \mathrm{mj} / \mathrm{m}^{2} /\right.$ day) resulted in decreasing Eta by $1.81 \mathrm{~m}^{3} / \mathrm{fed}$. Simultaneously data illustrates that increasing evaporation by $0.008 \mathrm{~mm} /$ day led to decrease Eta by $8.92 \mathrm{~m}^{3} / \mathrm{fed}$. Thus, water use efficiency WUE increases spontaneously by (136\%) and (119\%) for seed and straw yield, as soil heat flux increased by $0.021 \mathrm{mj} / \mathrm{m}^{2} / \mathrm{day}$, respectively. From the aforementioned data, we advise by using irrigation treatment $80 \%$ coupled with $1 \%$ organic matter which save about $20 \%$ from main applied water this ratio will increase seed yield by $402 \mathrm{~kg}$ $(36 \%)$. Also, at drought condition the farmer can use irrigation treatment $60 \%$ whereas save about $39 \%\left(675 \mathrm{~m}^{3}\right)$ if it use under the same organic matter (1\%) which could enhance seed yield by $27 \%$.
\end{abstract}

Key wards: Soil heat flux (G), thermal conductivity $(\lambda)$, Evaporation, water use efficiency (WUE).

\section{Introduction}

The amount of thermal energy that moves through an area of soil in a unit of time is the soil heat flux or heat flux density. The ability of a soil to conduct heat determines how fast its temperature changes during a day or between seasons (Thomas \& Robert 2005).

Soil heat flux $(\mathrm{G})$ is important in micrometeorology because it effectively couples energy transfer processes at the surface (surface energy balance) with energy transfer processes in the soil (soil thermal regime). This interaction between surface and subsurface energy transfer processes has led to detailed investigations of soil heat flux for a wide variety of agricultural applications.

The magnitude of $G$ as a component of the surface energy balance varies with surface cover, soil moisture content, and solar irradiance. Daytime peak hourly values of $G$ for a bare, dry soil in midsummer could be in excess of $300 \mathrm{Wm}^{-2}$ (Fuchs \& Hadas, 1972). By contrast, hourly $G$ for a moist soil beneath a plant canopy, residue layer, or snow cover will often be less than $\pm 20 \mathrm{~W} \mathrm{~m}^{-2}$. Surface soil heat flux typically represents 1 to $10 \%$ of $R$ n for growing crops (Baldocchi et al., 1985; Clothier et al., 1986)

Soil heat flux density could be measured using one of four methods (flux plate, calorimetric, gradient, or combination) (Thomas and Robert 2005). Therefore, this study aimed to calculate soil heat flux $(G)$ by using the gradient one which Fourier's Law is applied $\quad \boldsymbol{G}=-\lambda \Delta \boldsymbol{T} / \Delta \boldsymbol{z}$. Where $\lambda$ is the thermal conductivity of the soil ( $\mathrm{W} \mathrm{m}-1 \mathrm{~K}-1)$ and $\Delta T / \Delta z$ is the vertical temperature gradient $(\mathrm{K} \mathrm{m}-1)$ of the soil layer, (Hillel, 2004).

Thermal conductivity is the quantity of heat transferred through a unit area of the conducting body such as soil in unit time under a unit temperature gradient. The thermal conductivities of specific soil constituents differ widely. Hence the space-averaged thermal conductivity of a soil depends on its mineral composition and organic matter content as well as the volume composition of water and air (Hillel, 2003 and Abu-Hamdeh \& Reeder, 2000). These properties often vary between soils, spatially at the soil surface for the same soil, between layers within a soil, and over time.

The thermal conductivities of wet soil porous particles increased with increasing temperature in contrast to the behavior of dry beds and this Increase was attributed to a greater thermal conductivity of water as well as to the temperature-dependent equivalent thermal conductivities arising from steam diffusion (Ssing et al 1997\& Clothier,et al 1986). 
(Farouki, 1986), found an increase in either the saturation or dry density of a soil will result in an increase in its thermal conductivity. Also, thermal conductivity increased with increasing soil density and moisture content, (Kathleen et al. 2009).

Agricultural management practices including irrigation, drainage, and tillage have the potential to affect the thermal properties of soils and therefore soil thermal regime. In particular, the effect of tillage and crop residue management on soil heat flux has been the subject of several studies (Richard and Cellier, 1998 \& Sauer et al., 1998). Tillage loosens the surface soil, although some local compaction also may occur. Lower soil bulk density generally translates to lower $\lambda$, thus, lower $G$ has been observed in tilled soil as compared with un-tilled or compacted soil (Richard \& Cellier, 1998). Crop residue has a low thermal conductivity and, whether lying on the soil surface or incorporated into the soil by tillage, may inhibit heat transfer into the soil. Residue layers also have a shortwave reflectivity that is higher than most soils and provide a barrier to vapor flow (Sauer et al., 1997).

Thus, soils with a large proportion of the surface covered by crop residue as mulch tend to have higher water contents, lower temperatures, and lower $G$. Such changes in soil thermal regime, of course, have implications for the surface energy balance and evaporation.

Irrigation scheduling is one of the factors that influence the agronomic and economic viability of small farmer. It is important for both water savings and improved crop yields. The type of soil and climatic conditions have a significant effect on the main practical aspects of irrigation, which are the determination of how much water should be applied and when it should be applied to a given crop. Other important elements should also be considered, such as crop tolerance and sensitivity to water deficit at various growth stages, and optimum water use. Water shortage is a serious problem affecting plant growth and yield in the Mediterranean region (Souza et al., 2004).

Improving food crop production in the arid and semiarid regions. Influenced by multiple abiotic stresses, by strengthening a diversified crop production and introducing new climate-proof crops and cultivars with improved stress tolerance such as quinoa (chenopodium quinoa willd). Deficit irrigation strategy (DI) has been widely investigated as a valuable and sustainable production strategy in dry regions. By limiting water applications to drought sensitive growth stages, this practice aims to maximize water productivity and to stabilize, rather than maximize, yields (Geerts and Raes, 2009). Benefits of deficit irrigation derive from three factors: increased irrigation efficiency, reduced costs of irrigation and the opportunity costs of water (English and Raja, 1996). Quinoa (Chenopodium quinoa Willd.) comes from the Andean highlands of South America, It has a high nutritional value of protein, vitamins and minerals (Jensen et al.,2000), and it is drought and frost resistant crop (Garcia et al., 2003; 2007; Jacobsen et al.,2009, Jacobsen et al., 2005; 2007; Bois et al.,2006), and salt (Jacobsen et al., 2001; Jacobsen, 2009).

Thus, this study aims to explain the relationship between (1) thermal conductivity and soil organic matter and quantity of irrigation water, (2) soil thermal conductivity and heat flux, (3) heat flux and soil evaporation (4) heat flux and evapotranspiration (5) impact on water use efficiency.

\section{Materials and methods}

The field experiment was carried out in winter season of 2017/2018 and in split design in which the main plot was represented by three levels of composted farmyard manure application rates, i.e.0.0, 0.5 and $1 \%$. Sub-main plots were represented by three levels of irrigation water 60,80 and $100 \%$ with three replicates for each treatment. Thus, the experimental design is as follow: (3 rates for farmyard manure) x 3(irrigation water levels $\mathrm{x}$ 3 (replicates) $=27$ plots. After soil preparation, plots were divided into (5 lines/ plot) and sown by quinoa after seeds infuse in water for about twenty four hours, at (14 pits / line) at 15 th November 2017.

\section{Field Measurements:}

Soil thermal conductivity and heat flux measured monthly and calculated by Fourier' law according to (Hillel, 2004). Soil evaporation was determined according to (Richard et al., 1990). Organic matter (O.M) was determined as well as organic carbon (O.C) according to (Jackson, 1973) where, O.M \% = O.C $\% * 1.72$. The electrical conductivity determined using 4075Conductivity TDS meter described by (Jackson, 1973). The $\mathrm{pH}$ values of soil solution were determined by $3010 \mathrm{pH}$ meter According to (Black, 1983). The initial physical and chemical properties of Wadi Suder soil, farmyard manure and irrigation water shown in table (1).

Three irrigation water amounts (ETc) were obtained from the product of the potential evapotranspiration (ETo) by crop coefficient for every stage of quinoa then multiplying by $0.6,0.8$ and1.0 (i.e., (Q1) 100\%, (Q2)80\% and (Q3)60\%). The ETo was calculated from Penman-Monteith equation Allen et al. (1989). 
Table 1. Physical and chemical properties of initial soil, organic manure and irrigation water.

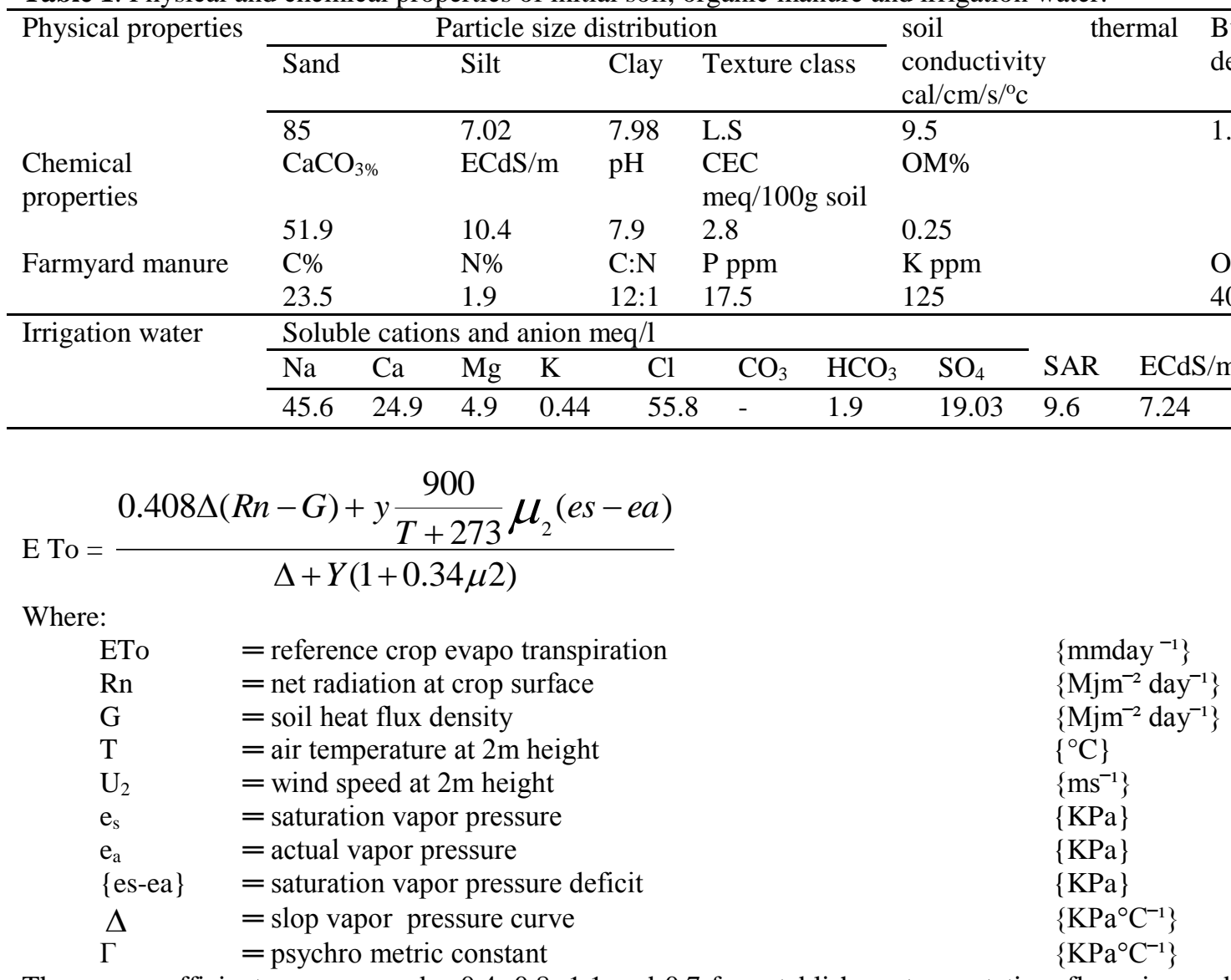

The crop coefficient was assumed as $0.4,0.8,1.1$ and 0.7 for establishment, vegetative, flowering and ripening stages, respectively.

Table 2. Applied water $\mathrm{m}^{3} / \mathrm{f}$

\begin{tabular}{|c|c|c|c|c|c|c|}
\hline \multirow{2}{*}{$\mathbf{Q}$} & \multicolumn{4}{|c|}{ ETc $_{\text {mm }}$} & \multirow{2}{*}{ 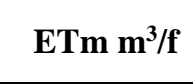 } & \multirow{2}{*}{$\begin{array}{l}\text { Applied } \\
\text { water } \mathbf{~ m}^{3} / \mathbf{f}\end{array}$} \\
\hline & In. & Dev. & Mid. & Lat. & & \\
\hline Q1 & 27.25 & 74.78 & 148.74 & 46.8 & 1250.22 & 1687.8 \\
\hline Q2 & 27.25 & 59.82 & 118.99 & 37.44 & 1000.18 & 1350.24 \\
\hline Q3 & 27.25 & 44.87 & 89.24 & 28.08 & 750.13 & 1012.62 \\
\hline
\end{tabular}

Q1=100\% Q2=80\% Q3=60\% In.= Initial stage Dev.= Development stage Mid.= Mid stage Lat.=Late stage

The recorded data were:

\section{1-Plant productivity}

Seed and straw yield $(\mathrm{kg} / \mathrm{fed}$.) were calculated for Quinoa plants

\section{2-Water consumptive use \\ 0 (Giriappa, 1983).}

\section{Results and discussion}

\section{Thermal conductivity:}

The thermal conductivity of soil varies by composition of the solid fraction (mineral type, particle size, and amount of organic matter), water content, and bulk density (Abu-Hamdeh \& Reeder, 2000). These properties often vary among soils, spatially at the soil surface for the same soil, between layers within a soil, and over time. So, entity of organic matter and applied water is desirable and momentous for its impression on thermal conductivity. Table (3) point out that thermal conductivity increased by 24, 26 and $65 \%$ as increasing of applied water, organic matter and their interaction. Figs. (1a\&1b) illustrate the linear relation of simple and multiple regression of OM and applied water and coupled of them, where, $y=15.29+4.09 \mathrm{x}_{1}$, $\mathrm{y}=7.21+0.123 \mathrm{x}_{2}$ and $\mathrm{y}=5.36+0.12 \mathrm{x}_{2}+4.1 \mathrm{x}_{1}$, where $\mathrm{y}, \mathrm{x}_{1}$ and $\mathrm{x}_{2}$ are thermal conductivity, organic matter and applied water, respectively. The simple and multiple correlations which assure these relations are: $\mathrm{r}=0.575^{*}, \mathrm{r}=0.712^{*}$ and $\mathrm{R}=0.917^{* * *}$ for organic matter, applied water and interaction, respectively. From the coefficient values of organic matter and applied water, it seems that thermal conductivity increased by 0.123 and 4.09 for each excessive unit of water and organic matter. 
Table 3. Soil thermal properties and evaporation affected by organic matter and applied water.

\begin{tabular}{lllll}
\hline $\begin{array}{l}\text { Farmyard. } \\
\text { manure }\end{array}$ & $\begin{array}{l}\text { Irrigation } \\
\text { Treatments }\end{array}$ & $\begin{array}{l}\text { Thermal } \\
\text { Conductivity } \\
\text { Cal/cm } / \mathrm{s} /{ }^{\circ} \mathrm{c}\end{array}$ & $\begin{array}{l}\text { Heat flux } \\
\mathrm{mJ} / \mathrm{m}^{2} / \text { day }\end{array}$ & $\begin{array}{l}\text { Evaporation } \\
\text { Mm/day }\end{array}$ \\
\hline \multirow{2}{*}{$0.0 \%$} & $100 \%$ & 17.66 & 0.0164 & 0.007 \\
& $80 \%$ & 14.26 & 0.0107 & 0.004 \\
$0.5 \%$ & $60 \%$ & 14.21 & 0.0088 & 0.003 \\
& $100 \%$ & 20.60 & 0.0222 & 0.009 \\
& $80 \%$ & 15.77 & 0.0124 & 0.005 \\
$1 \%$ & $60 \%$ & 15.20 & 0.0119 & 0.0048 \\
& $100 \%$ & 23.54 & 0.0293 & 0.012 \\
& $80 \%$ & 17.66 & 0.0156 & 0.0063 \\
\hline
\end{tabular}
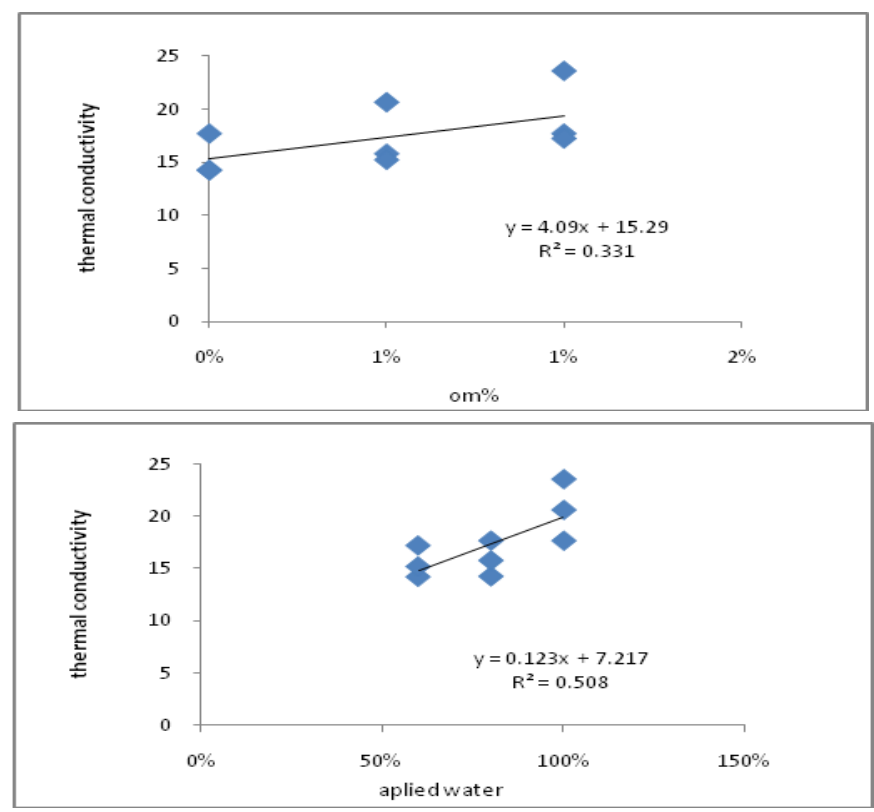

Fig. (1a) thermal conductivity affected by applied water and organic matter

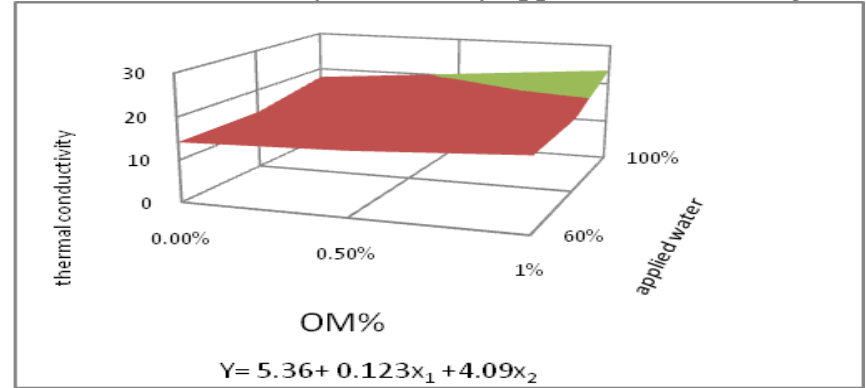

Fig. (1b) thermal conductivity affected by coupled of applied water and organic matter

\section{Heat flux:}

Measurement of soil heat flux density involves the measurement of soil temperature and one or more soil thermal properties (thermal conductivity or heat capacity), and possibly soil water and organic matter content. Wherever, soil with low heat capacity, organic matter, water content lower in its thermal content and conductivity consequently heat flux, therefore, this treatise aimed to study the relation of soil heat flux with soil organic matter, applied water and directly thermal conductivity. Table (3) declare that soil heat flux increased by 71,86 and $232 \%$ organic matter, applied water and inter action, respectively. Whereas, soil heat flux increase by 0.02 $\mathrm{mj} / \mathrm{m}^{2} /$ day as a result of increasing thermal conductivity by $9.33 \mathrm{cal} / \mathrm{cm} / \mathrm{s} /{ }^{\circ} \mathrm{c}$ (each $1 \mathrm{cal} / \mathrm{cm} / \mathrm{s} /{ }^{\circ} \mathrm{c}$ of thermal conductivity enhanced heat flux by 0.002 $\left.\mathrm{mj} / \mathrm{m}^{2} / \mathrm{day}\right)$. Figs $(2 \mathrm{a} \& 2 \mathrm{~b})$ come to emphasize these relations which show linear relation between thermal conductivity and heat flux and the complementary effect of organic matter and water on heat flux. The simple correlations were, $r=0.550^{*}, r=0.716^{*}$ and $r=$ $0.994 * * *$ for organic matter, applied water and thermal conductivity, by the same sequence. This means that thermal conductivity has superiority on 
applied water followed by organic matter. From the previous data we can conclude the following:

1:-Soil heat flux increased by increasing soil organic matter which causes enhance for both soil moisture and soil heat capacity.
2:- According to Fourier law soil heat flux correlated mathematically with thermal conductivity so, heat flux increased as thermal conductivity increase.

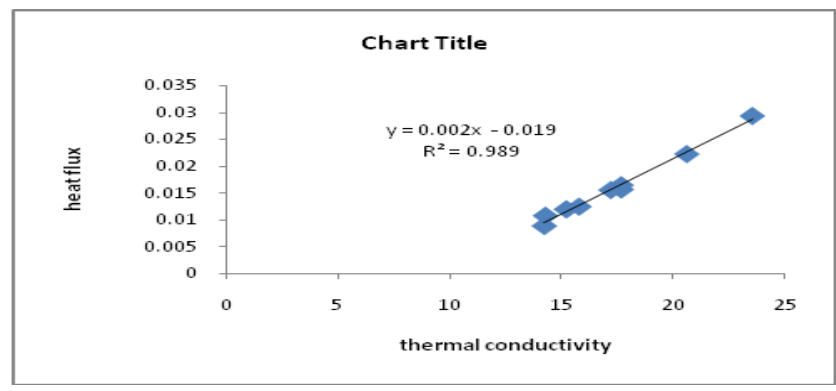

Fig (2a) heat flux affected by thermal conductivity.

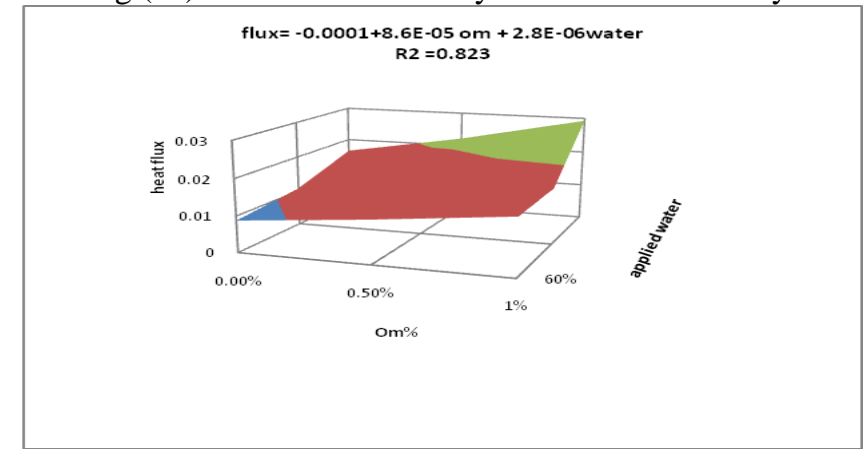

Fig (2b) heat flux affected by coupled of Om\% and applied water.

Soil evaporation and actual evapotranspiration (Eta):

Evaporation is a process by which water changes to a vapor through the absorption of heat energy. It is that part of evapotranspiration which occurs directly from water or moist surfaces. Evapotranspiration is the term used for combined evaporation and transpiration. It is defined as the sum of the volumes of water used per unit area by the vegetative growth in transpiration and that evaporated from the soil. Soil heat flux plays the major role in calculated the two items. However, soil heat flux defined as latent heat flux, sensible heat flux and density heat flux, the first is called the latent heat for evaporation this mean that evaporation increase with increasing latent heat. Also, penman montith for calculating evapotranspiration involves heat flux $(\mathrm{G})$ and net radiation in the equation. Whatever, tables $(3 \& 4)$ indicate that soil evaporation increase by $0.008 \mathrm{~mm} /$ day as heat flux increase by $0.021 \mathrm{mjm}^{-2} \mathrm{day}$, whilst, increasing soil heat flux $\left(1 \mathrm{mj} / \mathrm{m}^{2} /\right.$ day) resulted in decreasing Eta by $1.81 \mathrm{~m}^{3} /$ fed. On other side, the same table illustrates that increasing evaporation by $0.008 \mathrm{~mm} /$ day led to decrease Eta by $8.92 \mathrm{~m}^{3} / \mathrm{fed}$. Figs (3a, 3b \&3c) come to assure these relations +whereas, its show the linear relation between these parameters and the simple correlations were, $\mathrm{r}=0.94 * * *, \mathrm{r}=-0.621 *$ and $-0.618 *$ for (heat flux \& evaporation), (evaporation \& Eta) and (heat flux \& Eta), sequencely.

Table 4. Yield and consumptive water use efficiency.

\begin{tabular}{|c|c|c|c|c|c|c|}
\hline $\begin{array}{l}\text { Organic } \\
\text { Mater \% }\end{array}$ & $\begin{array}{l}\text { Water Levels } \\
\%\end{array}$ & $\begin{array}{l}\text { Seed yield } \\
\mathrm{Kg} / \mathrm{f}\end{array}$ & $\begin{array}{l}\text { Straw yield } \\
\mathrm{Kg} / \mathrm{f}\end{array}$ & $\begin{array}{l}\text { Eta } \\
\mathrm{m}^{3} / \mathrm{f}\end{array}$ & $\begin{array}{l}\text { Seed } \\
\text { WUE }\end{array}$ & $\begin{array}{l}\text { Straw } \\
\text { WUE }\end{array}$ \\
\hline \multirow{3}{*}{0} & 100 & 690 & 720 & 1300.85 & 0.530 & 0.55 \\
\hline & 80 & 621 & 661 & 1304.77 & 0.475 & 0.51 \\
\hline & 60 & 558 & 608 & 1305.40 & 0.427 & 0.47 \\
\hline \multirow{3}{*}{0.5} & 100 & 1076 & 1106 & 1298.47 & 0.828 & 0.85 \\
\hline & 80 & 960 & 995 & 1303.04 & 0.736 & 0.76 \\
\hline & 60 & 765 & 810 & 1302.28 & 0.585 & 0.62 \\
\hline \multirow{3}{*}{1} & 100 & 1304 & 1330 & 1296.14 & 1.010 & 1.03 \\
\hline & 80 & 1108 & 1150 & 1294.31 & 0.850 & 0.88 \\
\hline & 60 & 995 & 1040 & 1293.80 & 0.769 & 0.80 \\
\hline
\end{tabular}




\section{Quinoa yield:}

Quinoa yield comes as revenue of organic and applied water treatment and improved soil parameters whatever, table (4) point out that seeds yield increased by $82 \%$ as a result of organic matter increase, meantime, $23 \%$ and $133 \%$ attributed to applied water and the interaction, respectively. Also, Fig. (4) Assure these relations by showing the linear relation among seed yield and treatments. Meantime, the simple and multiple correlations were, $r=$ $0.881^{* *}, \mathrm{r}=0.431 \mathrm{NS}$ and $\mathrm{R}=0.921 * * *$, for organic matter, applied water and the interaction, respectively. Although the non significance of applied water but when coupled with organic matter it show the significant effect and the multiple regression is $\mathrm{y}=191.89+154.9 \mathrm{x}_{1}+7.6 \mathrm{x}_{2}$ where $\mathrm{y}, \mathrm{x}_{1}$ and $\mathrm{x}_{2}$ are seed yield, organic matter and applied water, respectively. Furthermore, there are three values of yield lie within the production limits of south Sinai soils (0.75: 1 ton/fed.), (guidance agrarian 2014) also, there are three values exceeds these limits by $7.6,10.8$ and $30.4 \%$. Seemingly, the six values which lie in the production limits or above it come as a result of using all application water levels under 0.5 and $1 \%$ organic manure and it take the order $(1 \%$ Om\& $100 \%$ AW $)>(1 \% \quad$ Om $\& 80 \% \mathrm{AW})>(0.5 \%$ Om \& $100 \% \mathrm{AW})>(1 \% \mathrm{Om} \&$ $60 \% \mathrm{AW})>(0.5 \% \mathrm{Om} \& 80 \% \mathrm{AW})>(0.5 \% \mathrm{Om} \&$ $60 \%)$.

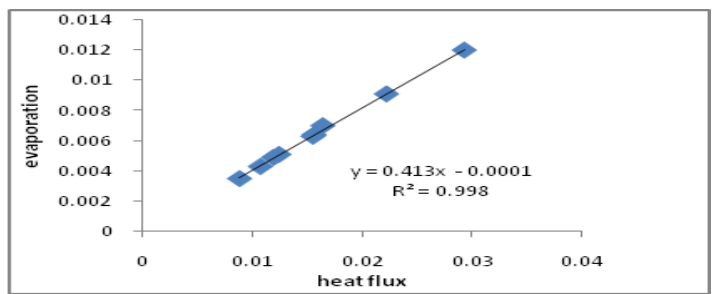

Fig. (3a) soil evaporation affected by heat flux.

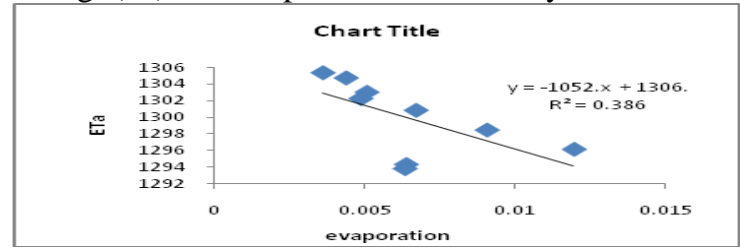

Fig. (3b) ETa affected by soil evaporation.

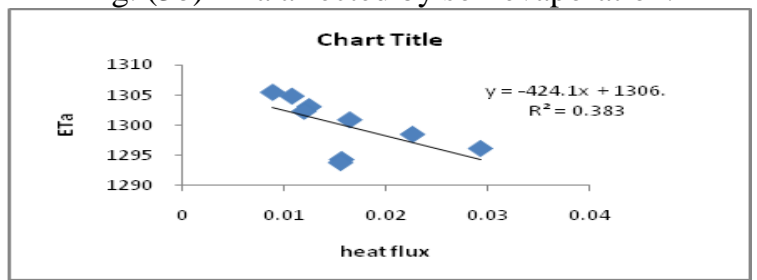

Fig. (3c) Eta affected by heat flux.

\section{Heat flux relation with quinoa seed yield.}

Soil heat flux affects on quinoa seed crop by indirect way where, raising heat flux means easiness energy translocation through rhizosphere and save the bio energy for all plant physiological process like, root elongation, nutrients uptake, water uptake and microbes activity. Whatever, the data shown in tables (3\&4) illustrate that there is a significant relation between soil heat flux and quinoa seed yield. Thereon, when calculate the difference between the maximum and minimum values of heat flux and seed yield it obvious that increase soil heat flux by $0.0205 \mathrm{mj} / \mathrm{m}^{2} /$ day exceed seed yield by $746 \mathrm{~kg} / \mathrm{fed}$., means that (each $0.01 \mathrm{mj} / \mathrm{m}^{2} /$ day give $363 \mathrm{~kg} / \mathrm{fed}$.). Fig. (4b), show the linear relation between soil heat flux and seed yield and the simple regression. The simple correlation is $0.819 * *$. These results agree with Samy(2001).

\section{Water use efficiency (WUE):}

Improving water use efficiency requires a development of satisfactory means to estimate crop water requirements or evapotranspiration (ETo). Water use efficiency as cumulative study involves ETa and yield. Also, soil heat flux affects indirectly on WUE through impact on Eta and evaporation. Table (4) declares that seed WUE increase by 83 , and $24 \%$ attributed to increasing organic matter and applied water, while, straw WUE raising reached 77 and $17 \%$ for organic matter and applied water, respectively. Meantime, tables $(3 \& 4)$ declare that increase soil heat flux by $0.021 \mathrm{mj} / \mathrm{m}^{2} /$ day resulted in increasing WUE $0.58(136 \%)$ and $0.56(119 \%)$ for seed and straw, respectively. Fig. (5), comes to emphasize the previous relation through the linear simple correlations which were, $r=0.430 \mathrm{NS}, \mathrm{r}=$ $0.881^{* *}$ and $0.823^{* *}$ for seed WUE whilst, for straw WUE were, $0.407 \mathrm{NS}, \mathrm{r}=0.891 * *$ and $\mathrm{r}=0.813 * *$ with 
applied water, organic matter and heat flux. From studying these correlation values it seems that applied water has a non significant effect on seed and straw WUE but when it coupled with organic matter and heat flux the relation had been changed. So that, the values of multiple correlations were $\mathrm{R}=0.982 * * *$ and
$\mathrm{R}=0.981 * * *$ for seed and straw WUE and the multiple regressions were: $\mathrm{Y}_{1}=0.139+0.36 \mathrm{x}_{1}+4.3 \mathrm{x}_{2}$ $+0.003 \mathrm{x}_{3}$ and $\mathrm{y}_{2}=0.2+0.35 \mathrm{x}_{1}+4.6 \mathrm{x}_{2}+0.003 \mathrm{x}_{3}$. Where, $\mathrm{y}_{1}, \mathrm{y}_{2}, \mathrm{x}_{1}, \mathrm{x}_{2}$ and $\mathrm{x}_{3}$ are seed WUE, straw WUE, organic matter, heat flux and applied water respectively.

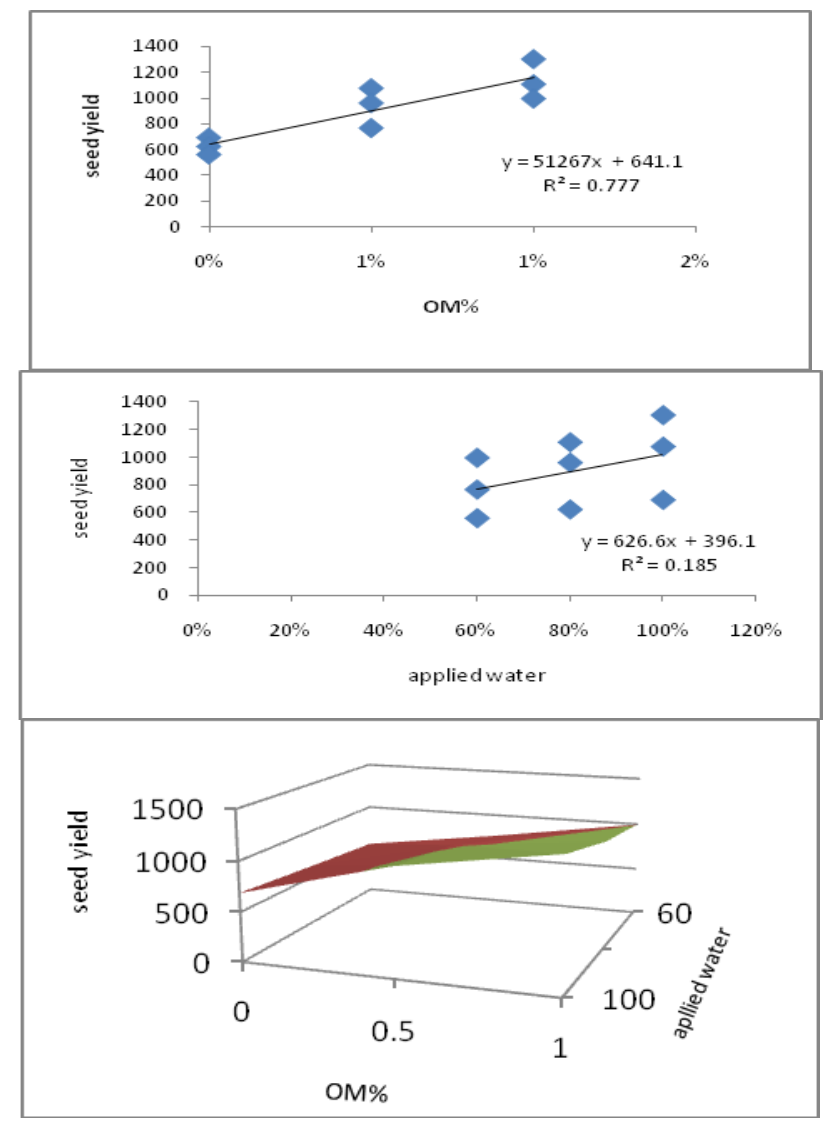

Fig.(4a). Seed yield affected by soil organic matter, applied water and their interaction.

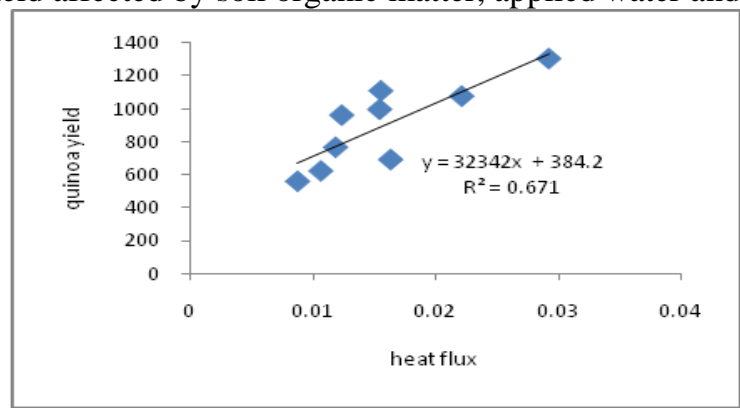

Fig.( 4b) seed yield affected by soil heat flux
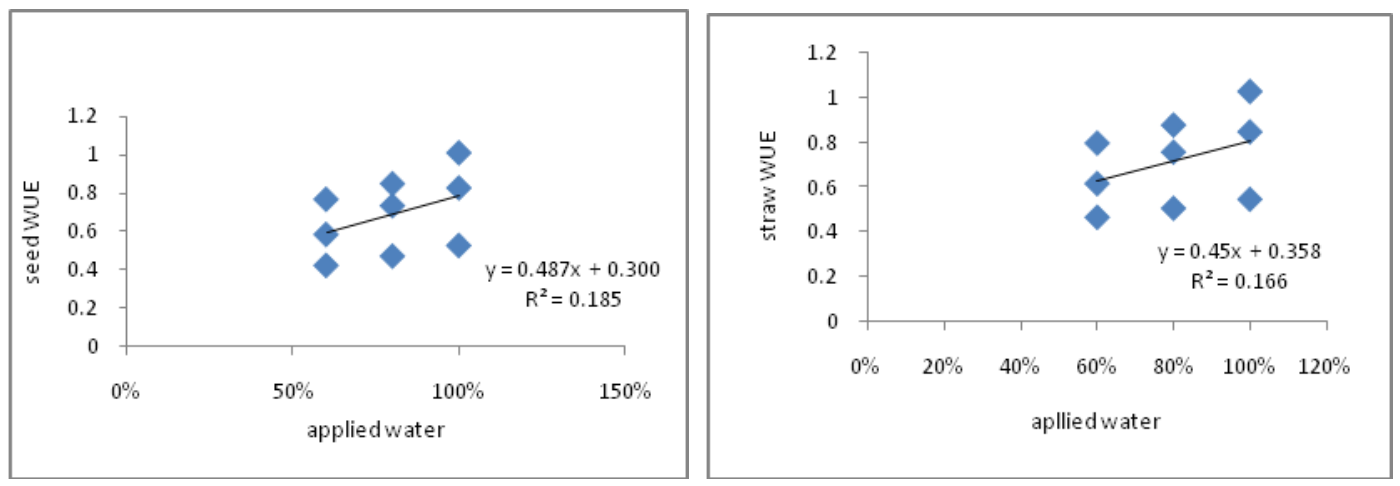


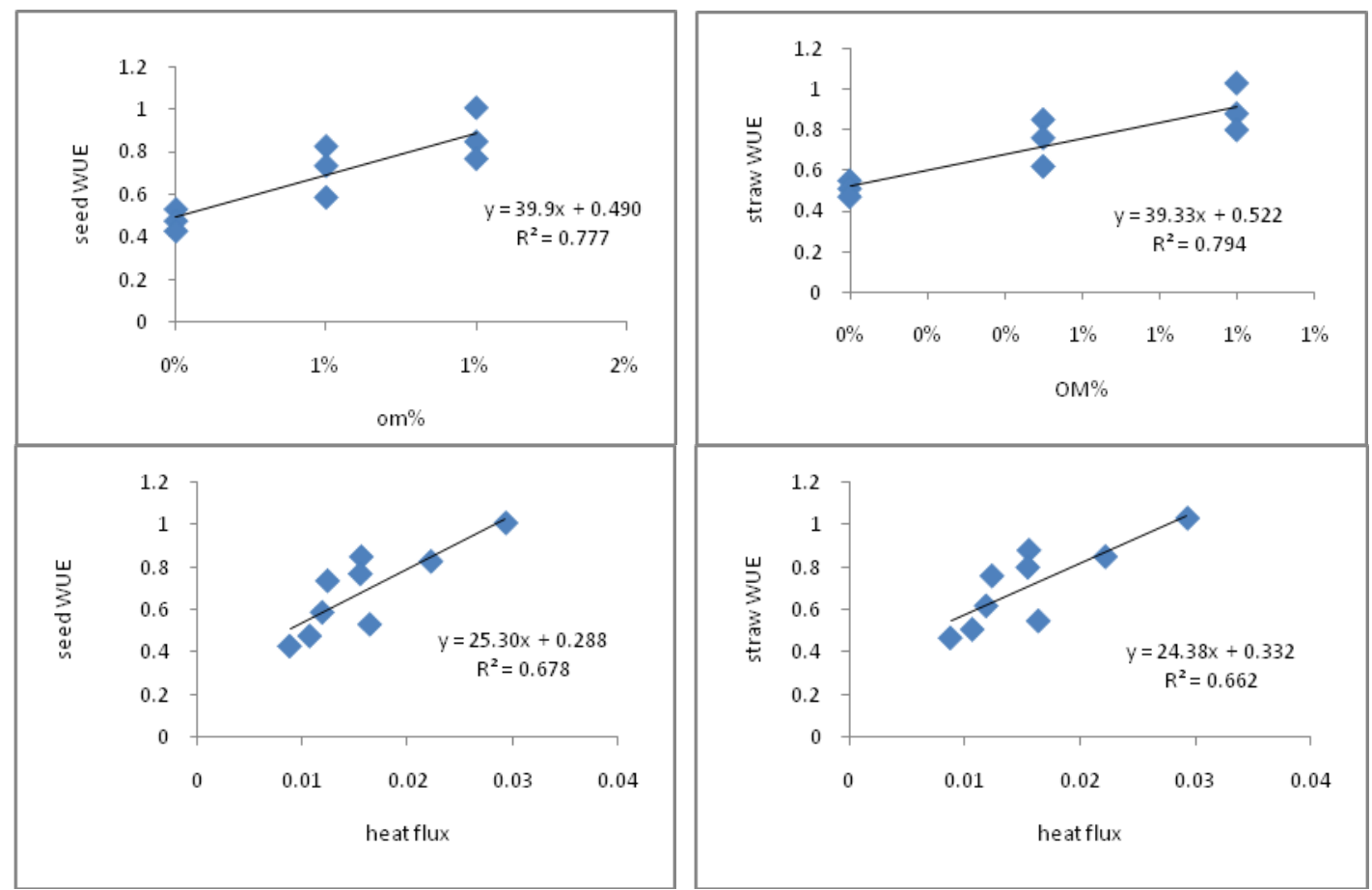

Fig. (5) WUE affected by applied water, organic matter and heat flux

\section{Conclusion}

Based upon results, the following can be concluded:

The effects of the applied treatments which improve most of studied soil characters terminally affect positively the crop yield parameters.

This complementally effect sustained over the studied successive season of cultivation with quinoa crop which indicate durability of these treatments in face of environmental and climatological conditions. The obvious role of organic matter and irrigation water in producing crops has been detected with yield parameters, in which organic application had the major role in improving quinoa crop, ETa and WUE based upon it has the magnitude values of correlation. Whilst, organic matter and irrigation water led to increase thermal conductivity by mixing technique significantly effect on the all aforementioned studied parameters. Heat flux significantly and positively correlated with organic matter, irrigation water and thermal conductivity. So that, soil heat flux increase resulted in decrease Eta and increase soil evaporation, so that ETa decreases as evaporation increase. Water use efficiency for seed and straw yields come as the conclusion improvement of all parameter and heat flux cause the majority increase reach 139 and $119 \%$ for seed and straw yields followed by organic matter and irrigation water.

Eventually, from the aforementioned data we advise by using irrigation treatment $80 \%$ coupled with $1 \%$ organic matter which save about $20 \%$ from main applied water this ratio will increase seed yield by $402 \mathrm{~kg}(36 \%)$. Also, at drought condition the farmer can use irrigation treatment $60 \%$ whereas save about
$39 \%\left(675 \mathrm{~m}^{3}\right)$ if it use under the same organic matter (1\%) which could enhance seed yield by $27 \%$.

\section{References}

Abu-Hamdeh, N.H., and R.C. Reeder. 2000. Soil thermal conductivity: Effects of density, moisture, salt concentration, and organic matter. Soil Sci. Soc. Am. J. 64:1285-1290.

Allen, R.G., L.S. Pereira, D. Raes and M. Smith.1989.Crop evapotranspiration, guidelines for computing crop water requirements.Irrig. \& Drain. Paper, No. 56, FAO, Rom, Italy.

Baldocchi, D.B., S.B. Verma, and N.J. Rosenberg. 1985. Water use efficiency in a soybean field: Influence of plant water stress. Agric. For. Meteorol. 34:53-65.

Black, C.A. (1983). "Methods of Soil Analysis". Part 1. Agron series No. 9,Am. Soc .Agron .Mad.Wise., U.S.A.

Bois, J. F.; T. Winkel, J. P. Lhomme, J. P. Raffaillac and A. Rocheteau. 2006. Response of some Andean cultivars of quinoa (Chenopodium quinoa Willd.) to temperature: effects on germination, phenology, growth and freezing. European Journal of Agronomy 25: 299308.

Clothier, B.E., K.L. Clawson, P.J. Pinter, Jr., M.S. Moran, R.J. Reginato, and R.D.

Jackson. 1986. Estimation of soil heat flux from net radiation during the growth of

English, M. and S. N. Raja. 1996. Perspectives ondeficit irrigation. Agricultural Water Management32 (1): 1-14.

Farouki, Omar T., 1986.Thermal Properties of Soils, Trans Tech Publications. 
Fuchs, M. and A., Hadas 1972. The heat flux density in a nonhomogeneous bare loessial soil. Boundary-Layer Meteorol., 3: 191-200.

Geerts, S. and D. Raes. 2009. Deficit irrigation as anon-farm strategy to maximize crop water productivity in dry areas. gricultural WaterManagement 96 (9): 1275-1284.

García, M.; D. Raes and S. -E. Jacobsen. 2003. Evapotranspiration analysis and irrigationrequirements of quinoa (Chenopodium quinoa) inthe Bolivian highlands. Agricultural WaterManagement 60: 119-134.

García, M.; D. Raes, S. -E. Jacobsen and T. Michel. 2007. Agroclimaticcontraints for rainfed agriculturein the Bolivian Altiplano. Journal of AridEnvironments 71: 109-121.

Giriappa, S. 1983. Water use efficiency in agriculture. Agricultural Development and Rural Transformation Unit. Institute for Social and Economic Change Bangalore. Oxford \& IBH Publishing Co.

Guidance agrarian, Ministry of agriculture and soil reclamation, Egypt, 2014

Hillel, D 2003. Introduction to environmental soil physics. Academic Press Limited, London, 484 pp

Hillel, D 2004. Soil temperature and heat flow. CE/ Enve 320-Vadose Zone Hydrology/ Soil physics pp. 309-316.

Jackson, M.L. 1973. Soil chemical analysis. Prentice -Hall, Inc England Clif, New Jersey, U.K

Jacobsen, S. -E.; H. Quispe and A. Mujica. 2001. An alternative crop for saline soils in the Andes. In: Scientist and Farmer - Partners in Research for the 21st Century. CIP Program Report 19992000: 403- 408.

Jacobsen, S. -E.; C. Monteros, J. L. Christiansen, L. A. Bravo, L. J. Corcuera and A. Mujica. 2005. Plant responses of quinoa (Chenopodium quinoa Willd.) to frost at various phenological stages. European Journal of Agronomy 22: 131139.

Jacobsen, S. -E.; C. Monteros, L. J. Corcuera, L. A. Bravo, J. L. Christiansen and A. Mujica. 2007. Frost resistance mechanisms in quinoa (Chenopodium quinoa Willd.). European Journal of Agronomy 26: 471-75.

Jacobsen, S. -E.; F. Liu and C. R. Jensen. 2009. Does root-sourced ABA play a role for regulation of stomata under drought in quinoa
(Chenopodium quinoa Willd.).ScientiaHorticulturae 122: 281-287.

Jensen, C. R.; S. -E. Jacobsen, M. N. Andersen, N. Núñez, S. D. Andersen, L. Rasmussen and V. O. Mogensen. 2000. Leaf gas exchange and water relation characteristics of field quinoa (Chenopodium quinoa Willd.) during soil drying. ur. Jour. Agron. 13: 11-25.

Kathleen M. S.; T. Sakaki; A. Limsuwat and T. H. Illangasekare 2009. Determination of the thermal conductivity of sands under varying moisture, drainage/wetting, and porosity conditionsapplications in near-surface soil moisture distribution analysis. Soil Sci. Soc. Am. J., 64, 1287-1291.

Richard, G., and P. Cellier. 1998. Effect of tillage on bare soil energy balance and thermal regime: An experimental study. Agronomie 18:163-181

Richard,G. A., S. P. Luis, , R. Dir. and, s. Marti, 1990. FAO irrigation and drainage paper No.56., Crop Evapotranspiration.

Samy,H.S.(2001).Water Use Efficiency and Water Economy of some Crops as affected by soil heat at Sinai. Ph. Thesis, soil department, Faculty of Agr., Zagazig univ.

Sauer, T.J., J.L. Hatfield, and J.H. Prueger. 1997. Over-winter changes in radiant energy exchange of a corn residue-covered surface. Agric. For. Meteorol. 85:279-287.

Sauer, T.J., J.L. Hatfield, J.H. Prueger, and J.M. Norman. 1998. Surface energy balance of a corn residue-covered field. Agric. For. Meteorol. 89:155-168.

Souza, R.P., E.C. Machado, J.A.B. Silva, A.M.M.A. Lagoa, andJ.A.G. Silveira. 2004. Photosynthetic gas exchange, chlorophyllfluorescence and some associated metabolic changes incowpea (Vignaunguiculata) during water stress and recovery. Environmental and Experimental Botany 51:45-56.

Ssing, W., H. Bu and J. Bart, (1997) Thermal conductivity of unsaturated packed beds comparison of experimental results and estimation methods, Chem. Eng. Process. 36 119132, alfalfa. Agric. For. Meteorol. 37:319-329.

Thomas J. S. and H. Rrobert, 2005. Soil Heat Flux. Copyright (C2005. American Society of Agronomy, Crop Science Society of America, Soil Science Society of America, 677 S. Segoe Rd., Madison, WI 53711, USA. Micrometeorology in Agricultural Systems, Agronomy Monograph no. 47. 


\section{تأثير التدفق الحرارى للتربة على الإستهلاك المائى للكينوا \\ جهان جمال عبد الغتى - مجدى حسن ذكى الرى \\ مركز بحوث الصحراء}

فى تجربة حقلية اقيمت فى شتاء 2017 فى محطة بحوث رأس سدر لتقييم تأثثر المادة العضوية وكمبات مباه الرى على التوصيل الحرارى و الدفق الحرارى للتربة وبالتالى على معدل البخر والبخر نتح وكفاءة استخدام المباه لمحصول الكينوا ـ نظريا يتم حساب البخر نتح من معادلة بنمان مونتيث

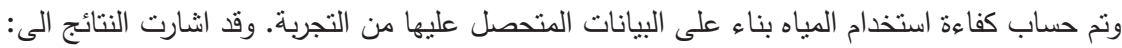

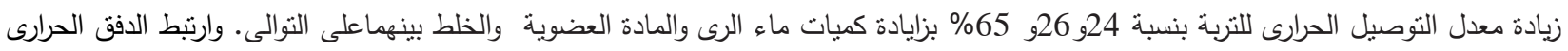
معنويا بكل المعاملات المدروسة وحقق نسب زيادة بلغت 71,86ور232 مع المادة العضوية والماء المضاف والتداخل بنهما على الترتيب. بينما زاد

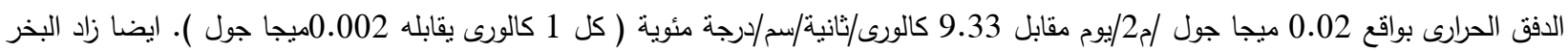
بمعدل 0.008 مم /يوم مقابل 0.021 ميجا جول دفق حرارى فى حين زيادة الدفق هذه خفضت البخر نتح 1.81مانق/فدان.

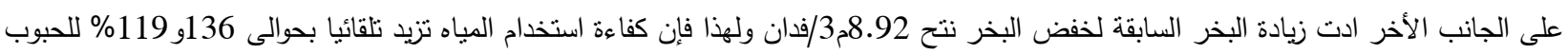
والقش على التوالى نتيجة للزيادة السابقة للدفق الحرارى •

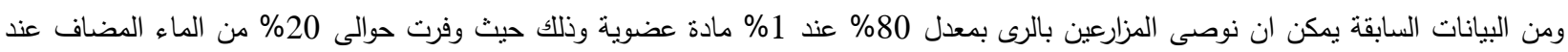

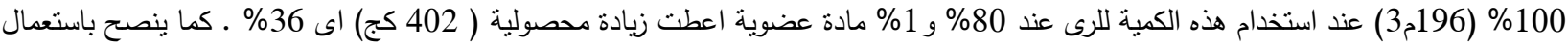

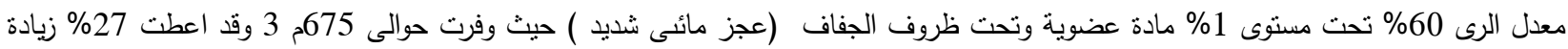
فى المحصول عند استخامها فى الرى عند 60\% من الماء المضاف و 1\% مادى مادة عضوية. 